\title{
Bromide substitution in lithium borohydride, $\mathrm{LiBH}_{4}-\mathrm{LiBr}$
}

\author{
L.H. Rude ${ }^{a}$, O. Zavorotynska ${ }^{b}$, L.M. Arnbjerg ${ }^{a}$, D.B. Raunsboek ${ }^{a}$, R.A. Malmkjør ${ }^{a}$, \\ H. Grove ${ }^{c}$, B.C. Hauback ${ }^{c}$, M. Baricco ${ }^{b}$, Y. Filinchuk ${ }^{d, e}$, F. Besenbacher ${ }^{f}$, T.R. Jensen ${ }^{a, *}$ \\ ${ }^{a}$ Center for Materials Crystallography (CMC), Interdisciplinary Nanoscience Center (iNANO) and Department of Chemistry, \\ Aarhus University, Langelandsgade 140, DK-8000 Århus C, Denmark \\ ${ }^{\mathrm{b}}$ Dipartimento di Chimica I.F.M. and NIS, Università di Torino, Torino, Italy \\ c Institute for Energy Technology, P.O. Box 40, Kjeller NO-2027, Norway \\ ${ }^{\mathrm{d}}$ Swiss-Norwegian Beam Lines at ESRF, BP-220, 38043 Grenoble, France \\ ${ }^{\mathrm{e}}$ Institute of Condensed Matter and Nanosciences, Université Catholique de Louvain, Place L. Pasteur 1, B-1348 Louvain-la-Neuve, Belgium \\ ${ }_{\mathrm{f}}^{\mathrm{f}}$ Interdisciplinary Nanoscience Center (iNANO) and Department of Physics and Astronomy, Aarhus University, DK-8000 Århus C, Denmark
}

\section{A R T I C L E I N F O}

Article history:

Received 22 May 2011

Received in revised form

29 August 2011

Accepted 30 August 2011

Available online $\mathrm{xxx}$

\section{Keywords:}

Hydrogen storage

Lithium borohydride

Anion substitution

In situ powder X-ray diffraction

Sieverts method

Infrared spectroscopy

\begin{abstract}
A B S T R A C T
By means of in situ synchrotron radiation powder X-ray diffraction, powder neutron diffraction, attenuated total reflectance infrared spectroscopy, differential scanning calorimetry and the Sieverts techniques we have investigated how anion substitution in the $\mathrm{LiBH}_{4}-\mathrm{LiBr}$ system leads to changes in the structural, physical, chemical and hydrogen storage properties of this material. Mechano-chemical treatment facilitates formation of a hexagonal solid solution $h-\operatorname{Li}\left(\mathrm{BH}_{4}\right)_{1-\mathrm{x}} \mathrm{Br}_{\mathrm{x}}$ whereas heating at elevated temperatures, i.e. $\mathrm{T}>112{ }^{\circ} \mathrm{C}$ appears to allow full solubility in the system $\mathrm{LiBH}_{4}-\mathrm{LiBr}$. The first step in the anion substitution process may be dissolution of small amounts of $\mathrm{LiBH}_{4}$ in $\alpha$ - $\mathrm{LiBr}$ deduced from observation of a hexagonal solid solution with unit cell volume similar to $\beta$ - $\mathrm{LiBr}$ for a hand-mixed sample. The solid solution, $\mathrm{Li}\left(\mathrm{BH}_{4}\right)_{1-\mathrm{x}} \mathrm{Br}_{\mathrm{x}}$, is isostructural to the hexagonal high temperature polymorph of $\mathrm{LiBH}_{4}$. This solid solution melts at a significantly higher temperature depending on the composition as compared to $h$ - $\mathrm{LiBH}_{4}$. Furthermore, a new hexalithium borate tribromide, $\mathrm{Li}_{6}\left(\mathrm{BO}_{3}\right) \mathrm{Br}_{3}$ was discovered and structurally characterized. Copyright @ 2011, Hydrogen Energy Publications, LLC. Published by Elsevier Ltd. All rights

reserved.
\end{abstract}

\section{Introduction}

The renewable energy sources, e.g. solar cells, wind turbines or wave energy, are sustainable, environmentally friendly, inexhaustible alternatives to fossil fuels. However, the widespread use of these energy sources is in general hampered by their fluctuation in time and their non-uniform distribution geographically [1-3]. One solution is the development of a safe, efficient and inexpensive energy storage system, and hydrogen is world-wide considered as an alternative energy carrier. Hydrogen is conveniently produced by electrolytic water splitting, but storage of hydrogen remains a significant unsolved problem [4-6]. A wide range of materials has been investigated during the past decade initially with a focus on magnesium or alanate based hydrides [7-11]. Sodium alanate is an excellent candidate for reversible storage of hydrogen, however, the capacity remains too low when measured on a system basis [12]. This has prompted intense research in metal borohydrides, which often have higher hydrogen contents [13-15].

Metal borohydride materials are interesting solid state hydrogen storage materials due to the generally high hydrogen content [14,15]. Unfortunately, the borohydrides

\footnotetext{
* Corresponding author. Tel.: +45 8942 3894; fax: +45 86196199.

E-mail address: trj@chem.au.dk (T.R. Jensen).
}

0360-3199/\$ - see front matter Copyright ๔ 2011, Hydrogen Energy Publications, LLC. Published by Elsevier Ltd. All rights reserved. doi:10.1016/j.ijhydene.2011.08.087 
usually have insufficient kinetic and thermodynamic properties, e.g. lithium borohydride, $\mathrm{LiBH}_{4}$, which contains $18.5 \mathrm{wt} \%$ $\mathrm{H}_{2}$ and $122.5 \mathrm{~g} \mathrm{H}_{2} / \mathrm{L}$, releases hydrogen at fairly high temperatures of $410{ }^{\circ} \mathrm{C}\left(p\left(\mathrm{H}_{2}\right)=1\right.$ bar $)$ [16]. The decomposition mechanism is generally described as shown in reaction scheme (1) [17]:

$$
2 \mathrm{LiBH}_{4} \rightarrow 2 \mathrm{LiH}+2 \mathrm{~B}+3 \mathrm{H}_{2} \quad \rho_{m}\left(\mathrm{H}_{2}\right)=13.97 \mathrm{wt} \%
$$

Although other decomposition products of $\mathrm{LiBH}_{4}$ have been observed, e.g. $\mathrm{Li}_{2} \mathrm{~B}_{12} \mathrm{H}_{12}$, none of them are well characterized and the rehydrogenation has been reported at harsh conditions, $\mathrm{T}=600^{\circ} \mathrm{C}$ and $p\left(\mathrm{H}_{2}\right)=155$ bar [18-21]. $\mathrm{LiBH}_{4}$ is known to exist in four polymorphic forms [22]. At ambient pressure and temperature, $\mathrm{LiBH}_{4}$ exhibits an orthorhombic structure (o$\mathrm{LiBH}_{4}$ ) with the space group Pnma (no. 62) and unit cell parameters $a=7.141(5), b=4.431(3), c=6.748(4) \AA$ [22]. Upon heating to $\sim 112{ }^{\circ} \mathrm{C}$, this structure transforms into a hexagonal polymorph $\left(h-\mathrm{LiBH}_{4}\right), a=4.3228(10)$ and $\mathrm{c}=7.0368(10) \AA$, with space group $\mathrm{P}_{3} \mathrm{mc}$ (no. 186) [23-25]. At high pressure, two structurally different polymorphs are identified with space group symmetries Ama2 (no. 40) and Fm-3m (no. 225) [23,26].

The properties of $\mathrm{LiBH}_{4}$ can be modified using appropriate additives, e.g. $\mathrm{SiO}_{2}, \mathrm{TiF}_{3}$ or $\mathrm{TiCl}_{3}$ [16,27-30]. Reactive hydride composites (RHC) may significantly improve the thermodynamic properties of $\mathrm{LiBH}_{4}$, e.g. as observed in the $2 \mathrm{LiBH}_{4}-\mathrm{MgH}_{2}$ system [31-38]. Anion substitution is another interesting strategy, which may stabilize the too unstable borohydrides or destabilize the too stable borohydrides [28,39-49]. Substitution of $\mathrm{BH}_{4}^{-}$with $\mathrm{Cl}^{-}, \mathrm{Br}^{-}$and $\mathrm{I}^{-}$anions in $\mathrm{LiBH}_{4}$ is reported to significantly improve the ion conductivity of $\mathrm{LiBH}_{4}$ [50-52].

This has prompted the present study of the mechanism for bromide, $\mathrm{Br}^{-}$, substitution in $\mathrm{LiBH}_{4}$ and the effect on hydrogen release in the system $\mathrm{LiBH}_{4}-\mathrm{LiBr}$. Lithium bromide, $\alpha$-LiBr, has a cubic NaCl-type structure (Fm-3m, no. 225) and a hexagonal polymorph, $\beta-\mathrm{LiBr}\left(\mathrm{P}_{3} \mathrm{mc}\right.$, no. 186) may be synthesized at $\mathrm{T} \leq 0^{\circ} \mathrm{C}$ using a substrate to initiate crystal growth [53-55]. We have used in situ synchrotron radiation powder X-ray diffraction (SR-PXD), powder neutron scattering (PND), attenuated total reflection infrared spectroscopy (ATR-IR), differential scanning calorimetry (DSC), and the Sieverts method, to study the effect of anion substitution on the structural, physical, chemical and hydrogen storage properties of $\mathrm{LiBH}_{4}$.

\section{Experimental}

Samples were prepared from mixtures of lithium borohydride, $\mathrm{LiBH}_{4},(95.0 \%$, Aldrich) and lithium bromide, $\alpha$ - $\mathrm{LiBr}(98.0 \%$, Fluka) in molar ratios of 1:0.25 (denoted S1), 1:0.5 (S2), 1:1 (S3) and 1:2 (S4) using mechano-chemical synthesis (ball milling). A sample for PND was prepared mixing $\mathrm{Li}^{11} \mathrm{BD}_{4}(98 \%$, KatChem) and $\alpha$-LiBr (98\%, Fluka) in the molar ratio $1: 1$ (denoted S5). All samples were ball milled under inert conditions (argon atmosphere) using a Fritch Pulverisette no. 4. The ball milling consists of $2 \mathrm{~min}$ milling intervened by $2 \mathrm{~min}$ breaks to avoid heating of the sample. This was repeated 60 times. The sample to ball ratio was 1:40 and tungsten carbide (WC) vial ( $80 \mathrm{~mL})$ and balls (Diameter: $10 \mathrm{~mm}$ ) was used.

A fraction $(\sim 0.5 \mathrm{~g})$ of the samples prepared same way as S1-S5 was transferred to corundum crucibles placed in a sealed argon filled quartz tube and annealed in a furnace kept at a fixed temperature of $280^{\circ} \mathrm{C}$ for $96 \mathrm{~h}$ (S1A, S2A, S3A and S4A) or $245^{\circ} \mathrm{C}$ for $72 \mathrm{~h}$ (S3B, S5B). Furthermore, a sample of $\mathrm{LiBH}_{4}-\mathrm{LiBr}$ in molar ratio 1:1 was prepared by hand mixing (HM) in an agate mortar for 10 min (denoted S6). All investigated samples are listed in Table 1.

Laboratory Powder X-ray Diffraction (PXD) were performed in Debye-Scherrer transmission geometry using a Stoe diffractometer equipped with a curved $\mathrm{Ge}(111)$ monochromator ( $\mathrm{Cu} \mathrm{K} \alpha_{1}$ radiation, $\lambda=1.54060 \AA$ ) and a curved position-sensitive detector. Data were collected at RT between 4 and $127^{\circ} 2 \theta$ with counting times of $\sim 280 \mathrm{~s}$ per step. The samples were mounted in a glovebox in $0.5 \mathrm{~mm}$ (outer diameter, o.d.) glass capillaries sealed with glue.

In situ SR-PXD data for sample S2 and S6 were measured at beamline BM01A at the Swiss-Norwegian Beam Lines (SNBL), European Synchrotron Radiation Facility (ESRF), Grenoble, France, using a MAR345 image plate detector. The samples were mounted in glass capillaries $(0.5 \mathrm{~mm}$ o.d.) sealed with a composite adhesive to prevent contact with air. The data were collected with a sample to detector

Table 1 - List of investigated samples. The composition of the samples is given as the molar ratios and the molar fractions, and the calculated hydrogen content is denoted $\rho_{m}\left(\mathrm{H}_{2}\right)$. The preparation methods are either ball milling $(\mathrm{BM})$ or handmixing in a mortar (HM) and in some cases combined with annealing in argon atmosphere.

\begin{tabular}{llcccc} 
Notation & Materials & Molar ratio & $n(\mathrm{LiBr}) / n($ total $)$ & Preparation & $\rho_{m}\left(\mathrm{H}_{2}\right)$ \\
\hline S1A & $\mathrm{LiBH}_{4}-\mathrm{LiBr}$ & $1: 0.25$ & 0.200 & $\mathrm{BM}, \mathrm{A}^{\mathrm{a}}$ & $\mathrm{BM}$ \\
S2 & $\mathrm{LiBH}_{4}-\mathrm{LiBr}$ & $1: 0.5$ & 0.333 & $\mathrm{BM}, \mathrm{A}^{\mathrm{a}}$ & 6.3 \\
S2A & $\mathrm{LiBH}_{4}-\mathrm{LiBr}$ & $1: 0.5$ & 0.334 & $\mathrm{BM}, \mathrm{A}^{\mathrm{c}}$ & 6.2 \\
S2C & $\mathrm{LiBH}_{4}-\mathrm{LiBr}$ & $1: 0.5$ & 0.334 & $\mathrm{BM}$ & 6.2 \\
S3 & $\mathrm{LiBH}_{4}-\mathrm{LiBr}$ & $1: 1$ & 0.498 & 3.7 \\
S3A & $\mathrm{LiBH}_{4}-\mathrm{LiBr}$ & $1: 1$ & 0.500 & $\mathrm{BM}, \mathrm{A}^{\mathrm{a}}$ & 3.7 \\
S3B & $\mathrm{LiBH}_{4}-\mathrm{LiBr}$ & $1: 1$ & 0.500 & $\mathrm{~B}^{\mathrm{b}}$ & 3.7 \\
S4A & $\mathrm{LiBH}_{4}-\mathrm{LiBr}$ & $1: 2$ & 0.665 & $\mathrm{BM}, \mathrm{A}^{\mathrm{a}}$ & 2.1 \\
S5B & $\mathrm{Li}^{11} \mathrm{BD}_{4}-\mathrm{LiBr}$ & $1: 1$ & 0.500 & $\mathrm{BM}, \mathrm{A}^{\mathrm{b}}$ & 3.7 \\
S6 & $\mathrm{LiBH}_{4}-\mathrm{LiBr}$ & $1: 1$ & 0.500 & $\mathrm{HM}$ & 3.7 \\
\hline
\end{tabular}

Conditions for annealing, ${ }^{a} 280^{\circ} \mathrm{C} / 96 \mathrm{~h},{ }^{\mathrm{b}} 245^{\circ} \mathrm{C} / 72 \mathrm{~h}$ and ${ }^{\mathrm{c}} 250^{\circ} \mathrm{C} / 5 \mathrm{~min}$. 
distance of $250 \mathrm{~mm}$ (S2) or $200 \mathrm{~mm}$ (S6) and with a $30^{\circ}$ (S2) or $60^{\circ}(\mathrm{S} 6)$ rotation of the capillaries during data collection. The X-ray exposure time was $30 \mathrm{~s}$ (S2) or $60 \mathrm{~s}$ (S6) using a selected wavelength of $\lambda=0.709595 \AA$ (S2) or $\lambda=0.770294 \AA$ (S6). The wavelength and the detector geometry were calibrated using an $\mathrm{LaB}_{6}$ external standard. Sample S2 was heated from $\mathrm{RT}$ to $300^{\circ} \mathrm{C}$ with a heating rate of $4{ }^{\circ} \mathrm{C} / \mathrm{min}$ and subsequently cooled to $26^{\circ} \mathrm{C}$ with a cooling rate of $4{ }^{\circ} \mathrm{C} / \mathrm{min}$. This procedure was repeated in three consecutive cycles for the same sample. Sample S6 was heated from RT to $300{ }^{\circ} \mathrm{C}$ with a heating rate of $1.5^{\circ} \mathrm{C} / \mathrm{min}$.

The high-resolution powder X-ray diffraction (HR-PXD) measurement $(\lambda=0.500860 \AA)$ for S5B was performed at the beamline BM01B at the SNBL, ESRF. A channel-cut monochromator $\mathrm{Si}(111)$ was used for wavelength selection. The diffractometer was equipped with six analyzer crystals, meaning that six complete patterns were collected simultaneously, with an offset of $1.1^{\circ} 2 \theta$ between the detectors. The sample was mounted in a glass capillary ( $0.5 \mathrm{~mm}$ o.d.) sealed with a composite adhesive to prevent contact with air.

SR-PXD data for sample S1A, S2A, S3A and S4A were measured at the beamline I711 at the MAX-II synchrotron in the research laboratory MAX-lab, Lund, Sweden $(\lambda=0.955 \AA$ ) with a MAR165 CCD detector system [56]. The samples were mounted in sapphire $\left(\mathrm{Al}_{2} \mathrm{O}_{3}\right)$ single crystal tubes $(1.09 \mathrm{~mm}$ o.d., $0.79 \mathrm{~mm}$ i.d.) in argon filled glovebox $\left(p\left(\mathrm{O}_{2}, \mathrm{H}_{2} \mathrm{O}\right)<0.5 \mathrm{ppm}\right)$ [57]. The SR-PXD experiments were conducted in argon atmosphere $(p(\mathrm{Ar})=1$ bar) at RT.

Powder neutron diffraction (PND) data were collected at RT on sample S5B with the PUS instrument at the JEEP II reactor at Kjeller, Norway [58]. Neutrons with wavelength $1.5553 \AA$ were obtained from a $\mathrm{Ge}(511)$ focusing monochromator. The detector unit consists of two banks of seven position-sensitive ${ }^{3} \mathrm{He}$ detectors, each covering $20^{\circ}$ in $2 \theta$ (binned in steps of $0.05^{\circ}$ ). Data were collected from 10 to $130^{\circ}$ in $2 \theta$. The sample was contained in a rotating cylindrical $6 \mathrm{~mm}$ diameter vanadium sample holder.

All SR-PXD data were integrated using the Fit2D program [59]. The SR-PXD data were analyzed by Rietveld refinement using the Fullprof suite [60], see further details in the supplementary information.

The novel compound hexalithium borate tribromide, $\mathrm{Li}_{6}\left(\mathrm{BO}_{3}\right) \mathrm{Br}_{3}$ was indexed from the HR-PXD and PND data collected on S5B using DICVOL2004 [61]. A hexagonal structural model was obtained using direct space algorithms implemented in the program FOX, $a=8.94084(6)$ and $c=5.77783(6) \AA$ with the space group symmetri $P 6_{3} / m m c$ [62]. The structural model was finally refined using the Rietveld method in the Fullprof suite [60]. The Rietveld refinement converged at $R_{B}=4.18 \%, R_{F}=3.84 \%, R_{p}=11.3 \%$ and $R_{\mathrm{wp}}=12.3 \%$.

Attenuated total reflectance infrared spectroscopy (ATRIR) measurements were performed for sample S2 and S2C heated to $250{ }^{\circ} \mathrm{C}$ (heating rate $50{ }^{\circ} \mathrm{C} / \mathrm{min}, p\left(\mathrm{H}_{2}\right)=250 \mathrm{mbar}$ ) using an ATR-IR spectrophotometer (Bruker Alpha equipped with the ATR single-reflection accessory with a diamond crystal), placed in a nitrogen filled glovebox (gas level: $\left.\mathrm{H}_{2} \mathrm{O}<0.1 \mathrm{ppm}, \mathrm{O}_{2}<0.5 \mathrm{ppm}\right)$. All spectra were measured at $\mathrm{RT}$ in the spectral-range 4000 to $375 \mathrm{~cm}^{-1}$ with $2 \mathrm{~cm}^{-1}$ resolution. Sixty four scans were averaged for each spectrum.
Differential scanning calorimetry (DSC) was performed with a Netzsch STA449C Jupiter instrument on sample S3 at a heating rate of $1.5^{\circ} \mathrm{C} / \mathrm{min}$ from $\mathrm{RT}$ to $410^{\circ} \mathrm{C}$ and on sample $\mathrm{R} 1$ at a heating rate of $1.5^{\circ} \mathrm{C} / \mathrm{min}$ from $\mathrm{RT}$ to $340^{\circ} \mathrm{C}$, both in a flow of $\mathrm{He}(50 \mathrm{~mL} / \mathrm{min})$. The samples were placed in $\mathrm{Al}_{2} \mathrm{O}_{3}$ crucibles with a small hole in the lid to prevent increase in pressure during desorption of gasses.

The cyclic stability of the substituted compounds was characterized by Sieverts measurements recorded on sample S2 with a Gas Reaction Controller from Advanced Materials Corporation [63]. The sample was loaded in a stainless steel autoclave in a glovebox with nitrogen atmosphere (gas level: $\left.\mathrm{H}_{2} \mathrm{O}<0.1 \mathrm{ppm}, \mathrm{O}_{2}<0.5 \mathrm{ppm}\right)$. Temperature-pressure desorption (TPD) experiments were performed in the temperature range $\mathrm{RT}$ to $500{ }^{\circ} \mathrm{C}$ with a heating rate of $4.5^{\circ} \mathrm{C} /$ min with a backpressure of $0.2-1$ bar of $\mathrm{H}_{2}$. Hydrogen absorption was measured at a fixed temperature of $415^{\circ} \mathrm{C}$ for $50 \mathrm{~h}$, applying an initial hydrogen pressure of ca. $100 \mathrm{bar}$. Three hydrogen desorption/absorption cycles were subsequently measured. In parallel, three desorption/absorption cycles on pure $\mathrm{LiBH}_{4}$ were measured at experimental conditions identical to those for sample $\mathbf{S} 2$.

\section{Results and discussion}

\subsection{Investigation of the mechanism for bromide substitution}

\subsubsection{Substitution by mechano-chemical treatment, ball} milling

Anion substitution is studied using in situ SR-PXD data measured for a ball milled sample of $\mathrm{LiBH}_{4}-\mathrm{LiBr}(1: 0.5, \mathrm{~S} 2)$, heated and cooled three times in the temperature range $26-300{ }^{\circ} \mathrm{C}\left(5{ }^{\circ} \mathrm{C} / \mathrm{min}\right)$, see Fig. 1 . The first diffractogram contains Bragg reflections from a hexagonal solid solution $h$ $\mathrm{Li}\left(\mathrm{BH}_{4}\right)_{0.47} \mathrm{Br}_{0.53}, \alpha$-LiBr and weak reflections from o- $\mathrm{LiBH}_{4}$

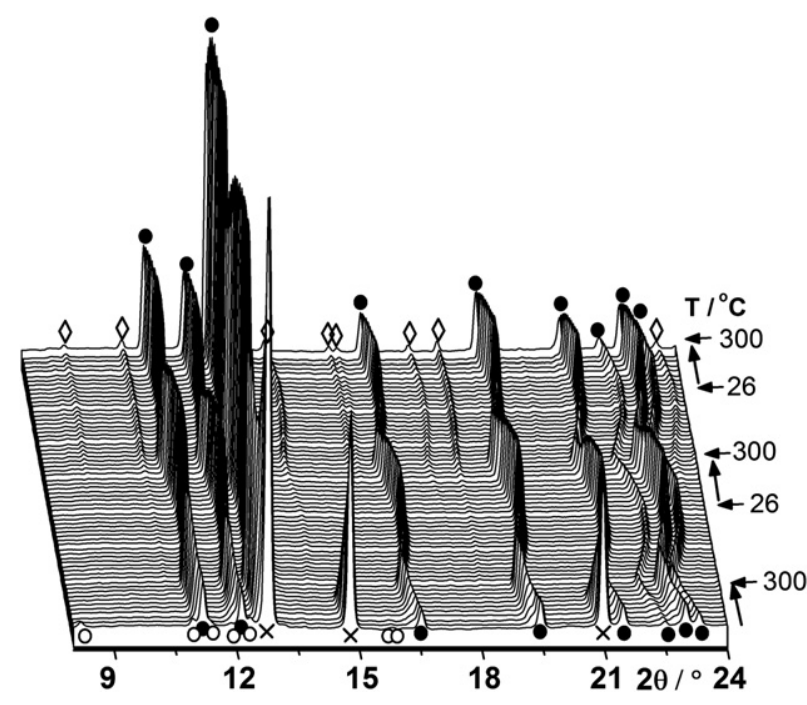

Fig. 1 - In situ SR-PXD data for $\mathrm{LiBH}_{4}-\mathrm{LiBr}(1: 0.5, \mathrm{~S} 2)$ heated from RT to $300{ }^{\circ} \mathrm{C}$ and cooled to RT three times (heating/ cooling rate $4{ }^{\circ} \mathrm{C} / \mathrm{min}, \lambda=0.709595 \AA$, ESRF, BM01B). Symbols: $\bigcirc$ o-LiBH $4, \times \alpha-\mathrm{LiBr}, \bigcirc \mathrm{h}-\mathrm{Li}\left(\mathrm{BH}_{4}\right)_{1-\mathrm{x}} \mathrm{Br}_{\mathrm{x}}, \diamond \mathrm{Li}_{6}\left(\mathrm{BO}_{3}\right) \mathrm{Br}_{3}$. 
(determined by Rietveld refinements). This reveals that a significant degree of anion substitution takes place during ball milling, which produces a solid solution.

During the first heating the intensity of the reflections from 0 - $\mathrm{LiBH}_{4}$ and $\alpha$ - $\mathrm{LiBr}$ gradually decreases, suggesting that o$\mathrm{LiBH}_{4}$ and $\alpha$ - $\mathrm{LiBr}$ gradually dissolves in the solid solution, $h$ $\mathrm{Li}\left(\mathrm{BH}_{4}\right)_{1-\mathrm{x}} \mathrm{Br}_{\mathrm{x}}$. A single phase solid solution with composition $h$ - $\mathrm{Li}\left(\mathrm{BH}_{4}\right)_{0.71} \mathrm{Br}_{0.29}$ is obtained during the first heating at $280^{\circ} \mathrm{C}$. However, during the second heating the formation of a novel compound, hexalithium borate tribromide, $\mathrm{Li}_{6}\left(\mathrm{BO}_{3}\right) \mathrm{Br}_{3}$, is observed, representing $10 \mathrm{wt} \%$ of the sample after the third heating. This compound may form due to the hygroscopic nature of lithium bromide, which may contain water.

\subsubsection{Anion substitution facilitated by hand mixing in} a mortar

A hand mixed (HM) sample of $\mathrm{LiBH}_{4}-\operatorname{LiBr}(1: 1, \mathrm{~S} 6)$ was investigated by in situ SR-PXD in the temperature range RT to $300^{\circ} \mathrm{C}$ and then cooled to RT to follow the substitution process. The first PXD pattern, measured at $25{ }^{\circ} \mathrm{C}$, contains Bragg reflections from $\alpha$ - $\mathrm{LiBr}$ and o- $\mathrm{LiBH}_{4}$, but also from the substituted solid solution, $h-\mathrm{Li}\left(\mathrm{BH}_{4}\right)_{1-\mathrm{y}} \mathrm{Br}_{\mathrm{y}}$ and a small amount of another compound, possibly $\mathrm{LiBr} \cdot \mathrm{H}_{2} \mathrm{O}$, which disappear at $\sim 60^{\circ} \mathrm{C}$, see Fig. 2. Five Bragg diffraction peaks were identified and indexed with a cubic unit cell, $a=4.0213 \AA$, which corresponds with that for $\mathrm{LiBr} \cdot \mathrm{H}_{2} \mathrm{O}, a=4.027 \AA$ [64]. The weight fraction of $h$ $\mathrm{Li}\left(\mathrm{BH}_{4}\right)_{1-\mathrm{y}} \mathrm{Br}_{\mathrm{y}}(3.8 \mathrm{wt} \%)$ is too small to allow determination of the bromide content in the solid solution prepared with the hand mixing procedure, i.e. compared to $67.9 \mathrm{wt} \%$ o- $\mathrm{LiBH}_{4}$, $26.9 \mathrm{wt} \% \alpha-\mathrm{LiBr}$, and $1.5 \mathrm{wt} \% \mathrm{LiBr} \cdot \mathrm{H}_{2} \mathrm{O}$. The small unit cell volume per formula unit $V / Z=50.9 \AA^{3}\left(T=25^{\circ} \mathrm{C}\right)$ for the solid solution $h$ - $\mathrm{Li}\left(\mathrm{BH}_{4}\right)_{1-\mathrm{y}} \mathrm{Br}_{\mathrm{y}}$, resembles the $\beta$ - $\mathrm{LiBr}$ structure $(\mathrm{V} /$ $\mathrm{Z}=49.6 \AA^{3}$ at $\mathrm{T}=-50{ }^{\circ} \mathrm{C}$ [55]) indicating that the substitution process possibly initiates with dissolution of $\mathrm{LiBH}_{4}$ in $\alpha$ - $\mathrm{LiBr}$, which stabilizes the $\beta$ - $\mathrm{LiBr}$ structure due to a small degree of $\mathrm{BH}_{4}^{-}$substitution during the grinding. The notation ' $\mathrm{y}$ ' is used for the solid solution in this case to distinguish from the solid

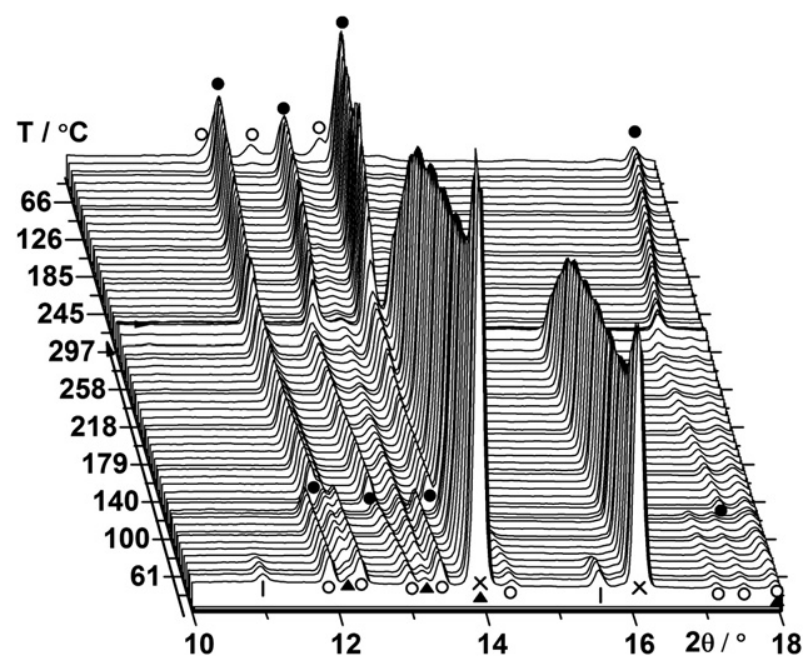

Fig. 2 - In situ SR-PXD data for hand mixed $\mathrm{LiBH}_{4}-\mathrm{LiBr}$ (1:1, S6) heated from $\mathrm{RT}$ to $300{ }^{\circ} \mathrm{C}$ (heating rate $4{ }^{\circ} \mathrm{C} / \mathrm{min}$, $\lambda=0.770294 \AA$ Å, ESRF, BM01B). Symbols: $\bigcirc_{0}-\mathrm{LiBH}_{4}, \Delta$ $h-\mathrm{Li}\left(\mathrm{BH}_{4}\right)_{1-\mathrm{y}} \mathrm{Br}_{\mathrm{y}}, \times \alpha-\mathrm{LiBr}, \bigcirc \mathrm{h}-\mathrm{Li}\left(\mathrm{BH}_{4}\right)_{1-\mathrm{x}} \mathrm{Br}_{\mathrm{x}}, \mid \mathrm{LiBr} \cdot \mathrm{H}_{2} \mathrm{O}$. solutions with larger unit cells, which resemble the structure of $\mathrm{LiBH}_{4}$.

Upon heating at $\mathrm{T}>40^{\circ} \mathrm{C}$, additional anion substitution is observed as decreasing diffracted intensity from $\alpha$-LiBr. The polymorphic phase transition from $0-\mathrm{LiBH}_{4}$ to a solid solution $h$ - $\mathrm{Li}\left(\mathrm{BH}_{4}\right)_{1-\mathrm{x}} \mathrm{Br}_{\mathrm{x}}$ with low bromide content is observed at $112{ }^{\circ} \mathrm{C}$, where the sample composition is $h-\mathrm{Li}\left(\mathrm{BH}_{4}\right)_{1-\mathrm{x}} \mathrm{Br}_{\mathrm{x}}$ ( 70.2 wt\%), $h-\mathrm{Li}\left(\mathrm{BH}_{4}\right)_{1-\mathrm{y}} \mathrm{Br}_{\mathrm{y}}(\sim 8.2 \mathrm{wt} \%)$ and $\alpha-\operatorname{LiBr}(21.6 \mathrm{wt} \%)$. The simultaneous existence of two hexagonal solid solutions with different composition, $y>x$, and a small difference in unit cell volumes per formula unit of $\sim 2.5 \AA^{3}$ are observed for the PXD patterns obtained in the temperature range $112-285^{\circ} \mathrm{C}$, see Fig. 3 and the Rietveld refinement shown in Fig. $\mathrm{s} 1$ in the supplementary information. Fig. 3 shows the unit cell volume per formula unit $(\mathrm{V} / \mathrm{Z})$ as a function of temperature extracted by sequential Rietveld refinement of the in situ SR-PXD data shown in Fig. 2. The change in the unit cell parameters $a$ and $c$ of $h-\mathrm{Li}\left(\mathrm{BH}_{4}\right)_{1-\mathrm{x}} \mathrm{Br}_{\mathrm{x}}$ and $h-\mathrm{Li}\left(\mathrm{BH}_{4}\right)_{1-\mathrm{y}} \mathrm{Br}_{\mathrm{y}}$ during the experiment is compared in the supplementary information in Fig. s2 showing a large impact on the unit cell parameter $c$ upon substitution. Furthermore, Fig. 2 reveals that the diffracted intensity from $\alpha$ - $\mathrm{LiBr}$ and $h-\mathrm{Li}\left(\mathrm{BH}_{4}\right)_{1-\mathrm{y}} \mathrm{Br}_{\mathrm{y}}$ decrease abruptly in the temperature range $249-296{ }^{\circ} \mathrm{C}$, simultaneously with an increase in intensity from $h$ $\mathrm{Li}\left(\mathrm{BH}_{4}\right)_{1-\mathrm{x}} \mathrm{Br}_{\mathrm{x}}$. At $296{ }^{\circ} \mathrm{C}$, full anion substitution is obtained resulting in a single phase solid solution of $\mathrm{Li}\left(\mathrm{BH}_{4}\right)_{1-\mathrm{x}} \mathrm{Br}_{\mathrm{x}}$ and a significant decrease in the unit cell volume in the temperature range $281-300{ }^{\circ} \mathrm{C}$ despite the expected thermal expansion due to continued heating clearly illustrated in Fig. 3. The solid solution is observed to be stable upon the cooling to $40^{\circ} \mathrm{C}$ where a fraction transforms from hexagonal to orthorhombic structure, i.e. formation of o- $\mathrm{Li}\left(\mathrm{BH}_{4}\right)_{1-\mathrm{x}} \mathrm{Br}_{\mathrm{x}}$ with $\mathrm{V} / \mathrm{Z}=53.5 \AA^{3}$, slightly smaller than that reported for o- $\mathrm{LiBH}_{4}\left(\mathrm{~V} / \mathrm{Z}=54.3 \AA^{3}\right)$ [65]. Formation of $0-\mathrm{Li}\left(\mathrm{BH}_{4}\right)_{1-\mathrm{x}} \mathrm{Br}_{\mathrm{x}}$ is observed as relatively broad Bragg peaks, which may indicate a less well defined composition of the individual crystal grains.

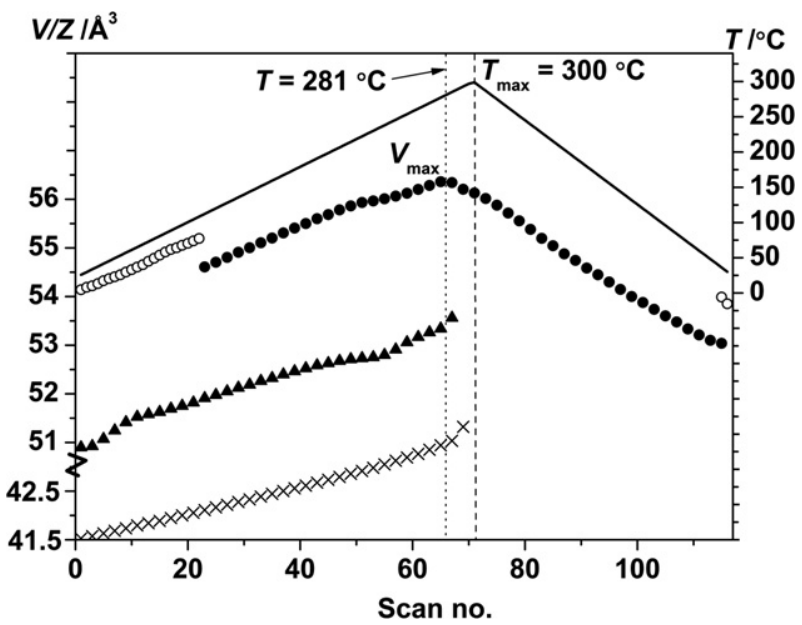

Fig. 3 - The unit cell volume per formula unit determined for $\mathrm{LiBH}_{4}-\operatorname{LiBr}(1: 1, \mathrm{S6})$ from the in situ SR-PXD data (shown in Fig. 2) in the temperature range from $R T$ to $300{ }^{\circ} \mathrm{C}$ (heating rate $4{ }^{\circ} \mathrm{C} / \mathrm{min}$ ). Symbols: $\bigcirc$ o- $\mathrm{LiBH}_{4}$, $\Delta h-\mathrm{Li}\left(\mathrm{BH}_{4}\right)_{1-\mathrm{y}} \mathrm{Br}_{\mathrm{y}}, \times \alpha-\mathrm{LiBr}, \bigcirc \mathrm{h}-\mathrm{Li}\left(\mathrm{BH}_{4}\right)_{1-\mathrm{x}} \mathrm{Br}_{\mathrm{x}}$. The temperature is shown as a solid line. 


\subsubsection{Substitution by annealing}

Anion substitution facilitated by thermal treatment is investigated for different compositions of $\mathrm{LiBH}_{4}-\mathrm{LiBr}$ prepared by annealing at $280{ }^{\circ} \mathrm{C}$ for $96 \mathrm{~h}$, i.e. 1:0.25 (S1A), 1:0.5 (S2A), 1:1 (S3A) and 1:2 (S4A). SR-PXD data for the four samples measured at RT two weeks after annealing are compared in Fig. 4. For sample S2A and S3A, a full substitution was obtained, i.e. less than 1 wt $\%$ excess $\alpha-\operatorname{LiBr}$ is observed. For sample S1A, a full substitution was also obtained, however, excess lithium borohydride is observed as o- $\mathrm{LiBH}_{4}$ (which may contain bromide) accounting for $\sim 18 \mathrm{wt} \%$ of the sample. For sample S4A, excess of $\alpha$ - $\mathrm{LiBr}$ is observed, accounting for $\sim 21 \mathrm{wt} \%$ of the sample. These results reveal that the hexagonal structure of $\mathrm{LiBH}_{4}$ can be stabilized at $\mathrm{RT}$ for extended periods of time and suggest the existence of a lower and an upper limit for the bromide substitution in $h-\mathrm{LiBH}_{4}$. The limits for anion substitution in the system $\mathrm{LiBH}_{4}-\mathrm{LiBr}$ appear to be 30-60 mol\% after two weeks at RT, i.e. h-Li(BH $\left(\mathrm{BH}_{4}\right)_{1-\mathrm{x}} \mathrm{Br}_{\mathrm{x}}$, $0.3<x<0.6$. Full solubility in the system $\mathrm{LiBH}_{4}-\mathrm{LiBr}$ is expected from the fact that both $\mathrm{LiBr}$ and $\mathrm{LiBH}_{4}$ are prone to adopt hexagonal structures with space group $\mathrm{P}_{3} \mathrm{mc}$ and that the ionic radii for $\mathrm{Br}^{-}$and $\mathrm{BH}_{4}^{-}$are very similar 1.96 and $2.03 \AA$, respectively $[55,66]$. The fact that stability limits to the degree of anion substitution in the system $\mathrm{LiBH}_{4}-\mathrm{LiBr}$ are observed may originate from differences in coordination properties of the $\mathrm{Br}^{-}$and $\mathrm{BH}_{4}^{-}$ions. Limited solubility is also observed for $\mathrm{LiBr}-\mathrm{LiI}$, i.e. $\mathrm{LiBr}_{1-\mathrm{x}} \mathrm{I}_{\mathrm{x}}$ with $0.25 \leq x \leq 0.8$ [53].

\subsubsection{Analysis of the stability of $\mathrm{Li}\left(\mathrm{BH}_{4}\right)_{1-x} \mathrm{Br}_{x}$}

Further investigation of the stability of anion substitution in the system $\mathrm{LiBH}_{4}-\mathrm{LiBr}$ was performed using an annealed (245 ${ }^{\circ} \mathrm{C}$ for $72 \mathrm{~h}$ ) sample (1:1, S3B) characterized by PXD after a few days and after 8 and 14 months and the sample composition was extracted by Rietveld refinement. A few days after the annealing a single phase solid solution and no $\alpha$ - $\mathrm{LiBr}$ was observed. However after 8 and 14 months ca. 22 and $38 \mathrm{wt}$ $\% \alpha$-LiBr, respectively, was observed in the sample. These

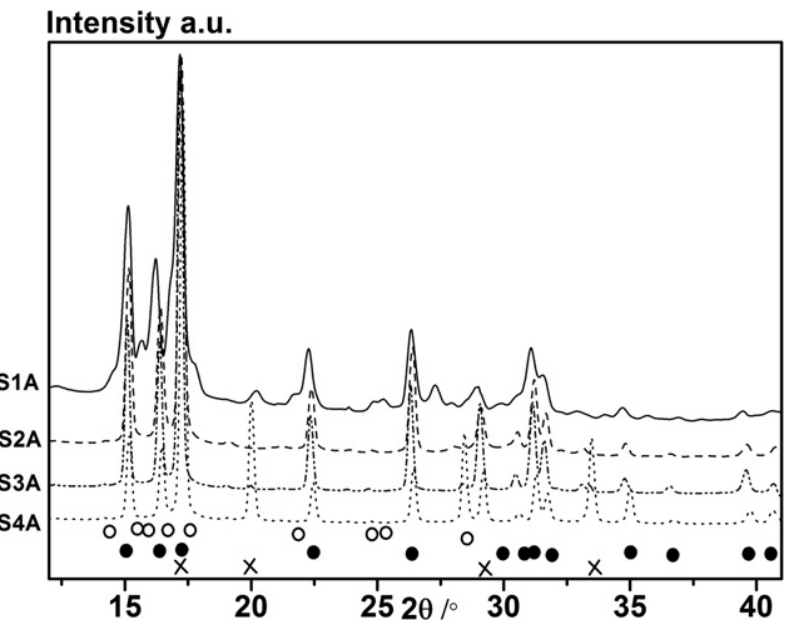

Fig. 4 - SR-PXD data measured for $\mathrm{LiBH}_{4}-\mathrm{LiBr}$ 1:0.25, S1A, (solid line), 1:0.5, S2A (dashed line), 1:1, S3A (dash-dot-dot), 1:2, S4A (dot). The data are collected at RT two weeks after annealing $\left(\lambda=0.9550 \AA\right.$, MAX-lab). Symbols: $\bigcirc$ o- $\mathrm{LiBH}_{4}$, $h-\mathrm{Li}\left(\mathrm{BH}_{4}\right)_{1-\mathrm{x}} \mathrm{Br}_{\mathrm{x}}, \times \alpha-\mathrm{LiBr}$. experiments reveal a slow segregation of $\alpha$-LiBr from the solid solution $h-\mathrm{Li}\left(\mathrm{BH}_{4}\right)_{1-\mathrm{x}} \mathrm{Br}_{\mathrm{x}}$ at $\mathrm{RT}$. Interestingly, the composition of the hexagonal solid solution remains approximately constant at, $h$ - $\mathrm{Li}\left(\mathrm{BH}_{4}\right)_{0.5} \mathrm{Br}_{0.5}$ over extended periods of time suggesting segregation of crystalline $\alpha$ - $\mathrm{LiBr}$ and amorphous o$\mathrm{LiBH}_{4}$ at RT. The experimental PXD data presented in Figs. 2 and 4 suggest that crystalline $\mathrm{o}-\mathrm{LiBH}_{4}$ may be segregated faster from a solid solution upon cooling. This shows that the hexagonal structure of $\mathrm{LiBH}_{4}$ is efficiently stabilized at RT by bromide substitution over extended periods of time. A slow segregation of $\mathrm{LiCl}$ at $\mathrm{RT}$ was also observed for solid solutions of $\mathrm{Li}\left(\mathrm{BH}_{4}\right)_{1-\mathrm{x}} \mathrm{Cl}_{\mathrm{x}}$ but in this case the stabilization of the hexagonal structure was less pronounced [39].

The results presented in this paper on anion substitution in the system the $\mathrm{LiBH}_{4}-\mathrm{LiBr}$ were reproduced several times using different samples with similar compositions. The formation of a metastable solid solution in the $\mathrm{LiBH}_{4}-\mathrm{LiBr}$ system suggests a slightly positive enthalpy of mixing, which can be easily overcome by mechanical and thermal treatments combined with the ease of forming hexagonal structures. Entropic contributions make the solid solution stable at high temperatures. The comparable ionic radii of $\mathrm{BH}_{4}^{-}$and $\mathrm{Br}^{-}$ lead to similar values of the charge-to-volume ratio, which are important for interactions in ionic compounds.

\subsection{Structural investigation of hexalithium borate tribromide, $\mathrm{Li}_{6}\left(\mathrm{BO}_{3}\right) \mathrm{Br}_{3}$}

The new compound hexalithium borate tribromide, $\mathrm{Li}_{6}\left(\mathrm{BO}_{3}\right) \mathrm{Br}_{3}$ has a hexagonal structure $a=8.94084(6), c=5.77783(6) \AA$ and space group $P 6_{3} / m m c$. The structure was solved and refined from SR-PXD and PND data shown in the supplementary information as Figs. s3 and s4, respectively. Atomic coordinates and selected bond lengths are given in the supplementary information, see Tables s1 and s2. The structural model contains two independent lithium positions and one position for boron, oxygen and bromide. The bromide anions coordinate to eight lithium atoms in a bicapped trigonal prismatic manner, whereas boron forms the trigonal planar composite anion $\mathrm{BO}_{3}^{3-}$. Each oxygen coordinate to one boron, two Li1 and two Li2. The closest neighbours of lithium Li1 is oxygen and at a greater distance $(>2.85 \AA$ ) are the bromide atoms found. Lithium Li2 coordinates to two oxygen and two bromide atoms with a bond length of 2.750(9) A additionally two bromide atoms are found at a distance of $2.8982(7)$. The new compound $\mathrm{Li}_{6}\left(\mathrm{BO}_{3}\right) \mathrm{Br}_{3}$ has a three dimensional framework structure illustrated in Fig. 5. Visual inspection of the structure reveals open hexagonal ' $\mathrm{LiBr}$ ' channels running along the c-axis and $5.54 \AA$ wide measured as the $\mathrm{Li} \cdots \mathrm{Br}$ distance across the channel. Hexalithium borate tribromide formed in several samples after prolonged heating possibly due to the hygroscopic nature of lithium bromide, which may contain water, i.e. as $\mathrm{LiBr} \cdot \mathrm{H}_{2} \mathrm{O}$ [64]. Recently, borohydride borates were discovered during release of hydrogen from $\mathrm{Ca}\left(\mathrm{BH}_{4}\right)_{2}$ and $\mathrm{LiBH}_{4}-\mathrm{Ca}\left(\mathrm{BH}_{4}\right)_{2}$, i.e. $\mathrm{Ca}_{3}\left(\mathrm{BH}_{4}\right)_{3}\left(\mathrm{BO}_{3}\right)$ and $\mathrm{LiCa}_{3}\left(\mathrm{BH}_{4}\right)\left(\mathrm{BO}_{3}\right)_{2}[31,67,68]$.

\subsection{Infrared spectroscopy of $\operatorname{Li}\left(\mathrm{BH}_{4}\right)_{1-x} \mathrm{Br}_{x}$}

In order to study the changes in the vibrational properties of bromide substituted lithium borohydride, IR-ATR spectroscopic 


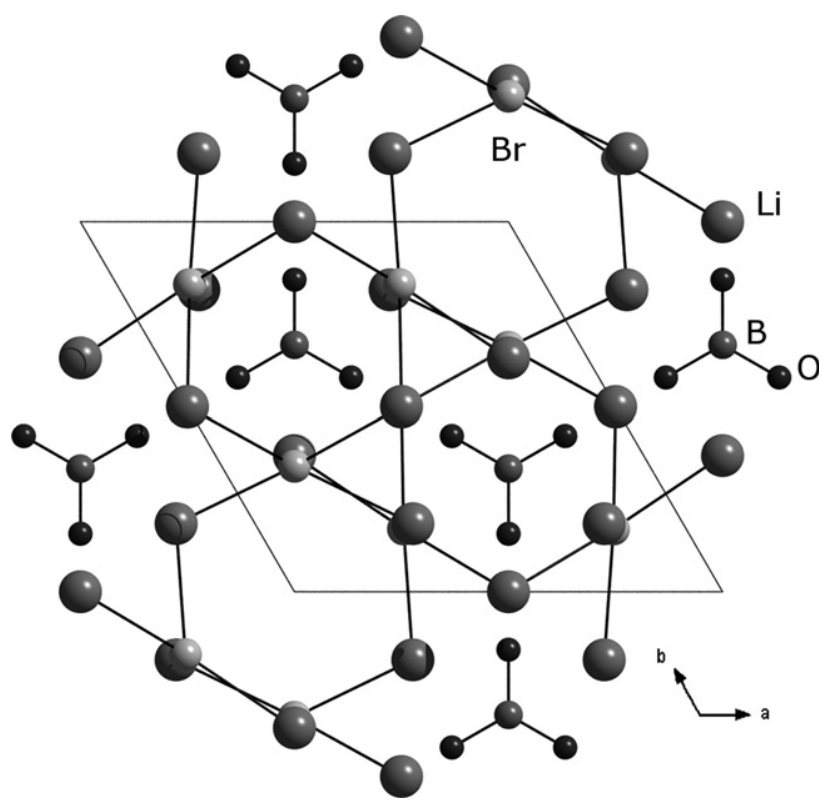

Fig. 5 - The structure of the hexalithium borate tribromide, $\mathrm{Li}_{6}\left(\mathrm{BO}_{3}\right) \mathrm{Br}_{3}$. The $\mathrm{BO}_{3}$ units coordinate to three lithium atoms in a trigonal planar coordination and the bromide anions coordinate to 8 lithium atoms each in a bicapped trigonal prismatic manner. Open hexagonal $\mathrm{LiBr}$ channels (5.54 $\AA \mathrm{Li} \cdots \mathrm{Br}$ distance across the channel) are found in the corners of the unit cell and are continuing through the structure along the c-axis.

measurements were performed on a sample of $\mathrm{LiBH}_{4}-\mathrm{LiBr}$ (1:0.5, S2), see Fig. 6. The IR-ATR spectrum of o- $\mathrm{LiBH}_{4}$ (R1), shown in Fig. 6 (a), reveal two main sets of peaks due to $B-H$ stretching (2400-2000 $\mathrm{cm}^{-1}$ region) and $\mathrm{H}-\mathrm{B}-\mathrm{H}$ bending $\left(1300-800 \mathrm{~cm}^{-1}\right)$ vibrational modes, as already reported [69-71].

The isolated $\mathrm{BH}_{4}^{-}$anion has an ideal tetrahedral symmetry, $\mathrm{T}_{d}$, however, the vibrational modes are split in the crystalline state due to lowering of the site symmetry from $T_{d}$ to $C_{s}$, i.e. the degenerate fundamental modes $\tilde{\nu}_{2}, \tilde{\nu}_{3}$, and $\tilde{\nu}_{4}$ split into several components. In $0-\mathrm{LiBH}_{4}$ (R1), Fig. 6 (a), the broad peak at $\sim 1420 \mathrm{~cm}^{-1}$ may be a combination band of $\mathrm{BH}_{4}^{-}$ librational movements in the crystal found at $\sim 400 \mathrm{~cm}^{-1}$ (see [72]) and the fundamental mode $\tilde{\nu}_{4}\left(\mathrm{~A}^{\prime \prime}\right)$ at $\sim 1050 \mathrm{~cm}^{-1}$. The spectrum of as-prepared $\mathrm{LiBH}_{4}-\operatorname{LiBr}(1: 0.5, \mathrm{~S} 2)$ exhibits similar vibrational features as o- $\mathrm{LiBH}_{4}$, see Fig. 6 (b) and (a), respectively, suggesting that $0-\mathrm{LiBH}_{4}$ is still present and predominant. However, a decrease in the intensity of the peak at ca. $1420 \mathrm{~cm}^{-1}$ and a small blueshift $\left(3-4 \mathrm{~cm}^{-1}\right)$ of all the absorption bands indicates the presences of a small amount of another compound. PXD performed prior to the IR-ATR experiment showed o- $\mathrm{LiBH}_{4}, \mathrm{LiBr}$ (which is not visible in the investigated spectral-range) and $h$ - $\mathrm{Li}\left(\mathrm{BH}_{4}\right)_{1-\mathrm{x}} \mathrm{Br}_{\mathrm{x}}$, see the Rietveld refinement profile in Fig. $\mathrm{s} 5$ in the supplementary information. In order to obtain increased substitution, the sample $\mathrm{LiBH}_{4}-\mathrm{LiBr}(1: 0.5, \mathrm{~S} 2)$ was heated to $250^{\circ} \mathrm{C}$ and cooled to RT. This resulted in differences in the $\mathrm{BH}_{4}^{-}$stretching and bending regions compared to the spectrum of o- $\mathrm{LiBH}_{4}$, see Fig. 6 (c), e.g. a decrease of the number of the components related to $\tilde{\nu}_{2}$ and

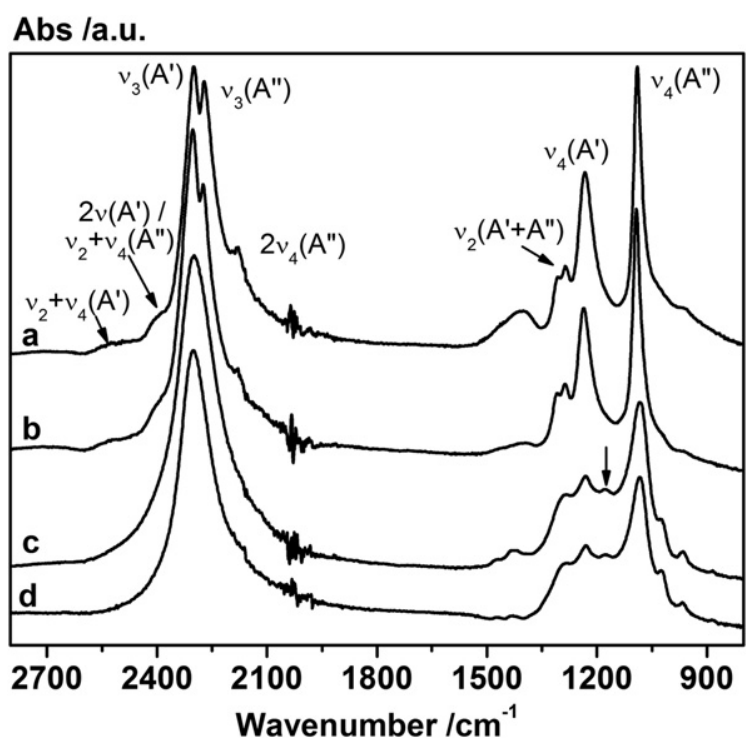

Fig. 6 - ATR-IR spectra of (a) $\mathrm{LiBH}_{4}$, (b) $\mathrm{LiBH}_{4}-\mathrm{LiBr}(1: 0.5, \mathrm{~S} 2)$, (c) $\mathrm{LiBH}_{4}-\mathrm{LiBr}(1: 0.5, \mathrm{S2C})$ after heating up to $250{ }^{\circ} \mathrm{C}$ at $5{ }^{\circ} \mathrm{C} /$ min, (d) the sample used in c re-measured after one month. IR active modes are indicated in the figure, following standard notation.

$\tilde{\nu}_{3}$ fundamental modes. In the structure of $h$ - $\mathrm{LiBH}_{4}$, the $\mathrm{BH}_{4}^{-}$ ions have $C_{3 \mathrm{v}}$ site symmetry and the $\tilde{\nu}_{2}$ mode is doubly degenerate, while $\tilde{\nu}_{3}$ has only two components. Therefore, the changes in the spectrum of Fig. 6 (c) with respect to Fig. 6 (a) may be related to the $C_{s}$ to $C_{3 v} B_{4}^{-}$site symmetry change, confirming the phase transition from o- to $h-\mathrm{LiBH}_{4}$ due to $\mathrm{Br}^{-}$ substitution. Similar changes upon heating have been reported for the Raman spectra of $\mathrm{LiBH}_{4}$ due to the polymorphic phase transition [70].

Furthermore, several new peaks can be observed in Fig. 6 (c): at $\sim 1170 \mathrm{~cm}^{-1}$ (marked with an arrow), 1020 and

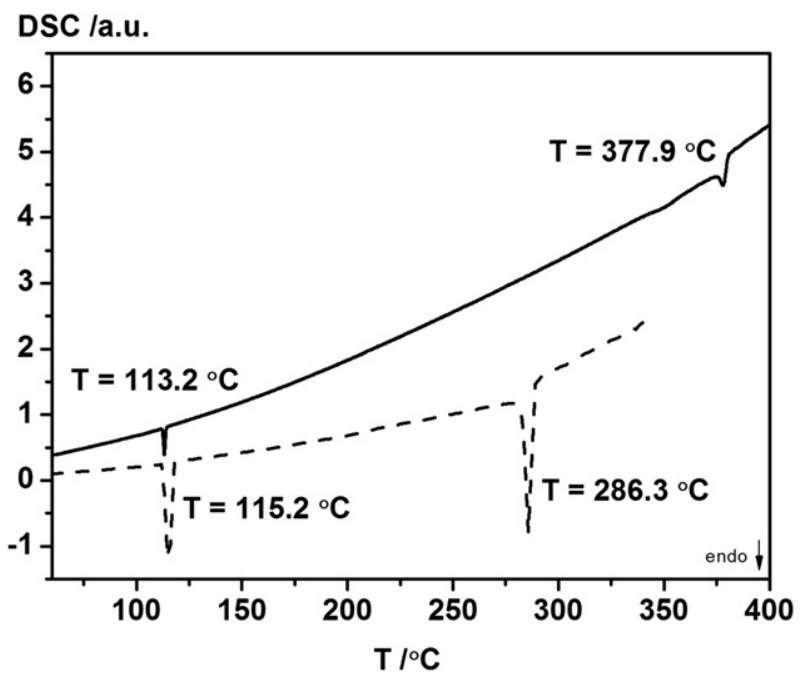

Fig. 7 - Differential scanning calorimetry (DSC) conducted from $R T$ to $400{ }^{\circ} \mathrm{C}$ for $\mathrm{LiBH}_{4}-\mathrm{LiBr}(1: 1, \mathrm{~S} 3$, solid line) and from $\mathrm{RT}$ to $340{ }^{\circ} \mathrm{C}$ for $\mathrm{LiBH}_{4}$ (R1, dashed line) using a heating rate of $1.5{ }^{\circ} \mathrm{C} / \mathrm{min}$. 
$958 \mathrm{~cm}^{-1}$. These peaks may be assigned to the fundamental modes of $\mathrm{BH}_{4}^{-}$, slightly shifted owing to the presence of $\mathrm{Br}$ anions in the lattice of a substituted compound, even if the straightforward assignment is rather difficult. The peak at $1420 \mathrm{~cm}^{-1}$ evidently decreases in intensity after $\mathrm{Br}$ substitution: A decrease in intensity of this peak can be related to alteration in the surroundings of $\mathrm{BH}_{4}^{-}$, i.e. a change of neighbouring atoms and/or distances between the ions in the lattice. This peak may also originate from oxide species, however, no crystalline oxides are observed in the sample during the experiment.

All these changes indicate the formation of the bromide substituted hexagonal compound $\mathrm{Li}\left(\mathrm{BH}_{4}\right)_{1-\mathrm{x}} \mathrm{Br}_{\mathrm{x}}$ formed due to the annealing. PXD performed on $\mathrm{LiBH}_{4}-\mathrm{LiBr}(1: 0.5, \mathrm{~S} 2 \mathrm{C}$, heated to $250^{\circ} \mathrm{C}$ and cooled to $\mathrm{RT}$ ) showed $h$ - $\mathrm{Li}\left(\mathrm{BH}_{4}\right)_{1-\mathrm{x}} \mathrm{Br}_{\mathrm{x}}$ and a small amount of residual $\alpha$ - $\mathrm{LiBr}$, see the Rietveld refinement profile in the supplementary information Fig. s5. The spectrum (d) in Fig. 6 measured one month after the annealing confirm the stability of the $\mathrm{Li}\left(\mathrm{BH}_{4}\right)_{1-\mathrm{x}} \mathrm{Br}_{\mathrm{x}}$ found by PXD.

\subsection{Investigation of the bromide substitution by differential scanning calorimetry}

Differential scanning calorimetry (DSC) was conducted in the temperature range $\mathrm{RT}$ to $400{ }^{\circ} \mathrm{C}$ with a heating rate of $1.5^{\circ} \mathrm{C} /$ min for $\mathrm{LiBH}_{4}-\mathrm{LiBr}(1: 1, \mathrm{~S} 3)$ and compared with o- $\mathrm{LiBH}_{4}$ (R1), see Fig. 7. The polymorphic transition from o- $\mathrm{LiBH}_{4}$ to $\mathrm{h}-\mathrm{LiBH}_{4}$ for the pure $\mathrm{LiBH}_{4}(\mathrm{R} 1)$ is observed at $115.2{ }^{\circ} \mathrm{C}$ and the melting point at $286.3^{\circ} \mathrm{C}$. For sample $\mathrm{LiBH}_{4}-\mathrm{LiBr}(1: 1, \mathrm{~S} 3)$ the signal from the polymorphic transition from o- to $h-\mathrm{LiBH}_{4}$ is found to be significantly weaker and the melting point has increased to $377.9^{\circ} \mathrm{C}$, i.e. a stabilization of $\mathrm{Li}\left(\mathrm{BH}_{4}\right)_{1-\mathrm{x}} \mathrm{Br}_{\mathrm{x}}$ compared to $\mathrm{LiBH}_{4}$. The DSC experiment was continued using the same sample, i.e. performing an additional heating. No DSC signal for the polymorphic transition and the melting point was observed within the measured temperature range. These results confirm that a large degree of $\mathrm{Br}$ anion substitution occurs during ball milling and that additional anion substitution occurs during thermal annealing, in agreement with the SRPXD results.

\subsection{Rehydrogenation properties of $\mathrm{Li}\left(\mathrm{BH}_{4}\right)_{1-x} \mathrm{Br}_{x}$}

The rehydrogenation properties of the $\mathrm{LiBH}_{4}-\mathrm{LiBr}$ system were investigated using the Sieverts method. Three hydrogen release and uptake cycles for $\mathrm{LiBH}_{4}-\operatorname{LiBr}(1: 0.5, \mathrm{~S} 2)$ and for $\mathrm{LiBH}_{4}$ are shown in Fig. 8 and hydrogen absorption measurements are shown in supplementary information Fig. 66.

A total hydrogen release of $12.4 \mathrm{wt} \%$ is observed for $\mathrm{LiBH}_{4}$, during the first dehydrogenation ( $89 \%$ of the theoretical capacity: $\left.\rho_{m}\left(\mathrm{H}_{2}\right)=13.88 \mathrm{wt} \%\right)$. A second and third dehydrogenation was measured for $\mathrm{LiBH}_{4}$ after $50 \mathrm{~h}$ of rehydrogenation, showing release of 6.1 and $5.3 \mathrm{wt} \%$ (44 and $38 \%$ of theoretical capacity). The dehydrogenation profile of $\mathrm{LiBH}_{4}-\mathrm{LiBr}(1: 0.5$, S2) is similar to the second dehydrogenation from $\mathrm{LiBH}_{4}$, see Fig. 8. A total hydrogen release of $5.6 \mathrm{wt} \%$ is observed for $\mathrm{LiBH}_{4}-\mathrm{LiBr}(1: 0.5$, S2), i.e. $90 \%$ of the theoretical capacity, $\rho_{m}\left(\mathrm{H}_{2}\right)=6.2 \mathrm{wt} \%$. A second and a third desorption was also measured showing hydrogen release of 2.8 and $2.3 \mathrm{wt} \% \mathrm{H}_{2}$ ( $45 \%$ and $37 \%$ of the theoretical capacity). The observed

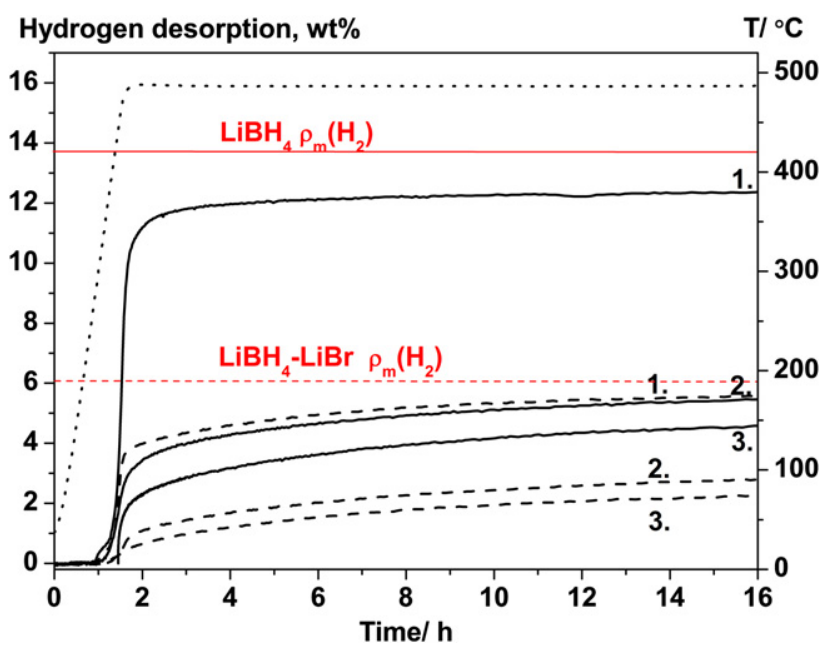

Fig. 8 - Sieverts measurements of $\mathrm{LiBH}_{4}-\mathrm{LiBr}(1: 0.5, \mathrm{~S} 2$, dashed line) compared with $\mathrm{LiBH}_{4}$ (R1, solid line), displayed as weight percentage versus time. Three cycles of desorption was measured, from RT to $500^{\circ} \mathrm{C}$ with $4.5^{\circ} \mathrm{C} / \mathrm{min}$ and left at this temperature for $15 \mathrm{~h}$. The temperature is shown as the dotted line. The theoretical hydrogen content in the sample (wt\%) is shown as horizontal lines.

decrease in hydrogen storage capacity may be due to incomplete hydrogen absorption, see Fig. $\mathrm{s} 6$ in the supplementary information. Thus, the reversible hydrogen storage capacity of the system $\mathrm{LiBH}_{4}-\mathrm{LiBr}$ is found to be $37 \%$ after 3 cycles, which is approximately the same as for $\mathrm{LiBH}_{4}$ showing 38\% reversibility after 3 cycles under the same conditions, i.e. the thermodynamics of the hydrogen uptake and release seems to be unchanged.

\section{Conclusion}

The mechanism for anion substitution in the system the $\mathrm{LiBH}_{4}-\mathrm{LiBr}$ facilitated by mechano-chemical or thermal treatment is investigated by in situ synchrotron radiation powder $\mathrm{X}$-ray diffraction and the data is analyzed by Rietveld refinement. Mechano-chemical treatment facilitates formation of a hexagonal solid solution $h$ - $\mathrm{Li}\left(\mathrm{BH}_{4}\right)_{1-\mathrm{x}} \mathrm{Br}_{\mathrm{x}}$ whereas heating at elevated temperatures $\mathrm{T}>112^{\circ} \mathrm{C}$ appears to allow full solubility in the system $\mathrm{LiBH}_{4}-\mathrm{LiBr}$. Hand mixing a sample of $\mathrm{LiBH}_{4}-\mathrm{LiBr}$ leads to formation of a hexagonal solid solution $h-\mathrm{Li}\left(\mathrm{BH}_{4}\right)_{1-\mathrm{x}} \mathrm{Br}_{\mathrm{x}}$ with small unit cell volume similar to $\beta$ - $\mathrm{LiBr}$, which suggest that the first step in the anion substitution process may be dissolution of small amounts of $\mathrm{LiBH}_{4}$ in $\alpha$-LiBr. Two solid solutions can be observed upon heating and the dissolution process is further accelerated at $\mathrm{T}>112^{\circ} \mathrm{C}$ resulting in a single phase solid solution at elevated temperatures. Cooling a solid solution $h$ - $\mathrm{Li}\left(\mathrm{BH}_{4}\right)_{1-\mathrm{x}} \mathrm{Br}_{\mathrm{x}}$ may lead to crystallisation of $\alpha$ - $\mathrm{LiBr}, \quad 0-\mathrm{Li}\left(\mathrm{BH}_{4}\right)_{1-\mathrm{x}} \mathrm{Br}_{\mathrm{x}}$ and/or a hexagonal solid solution $h-\mathrm{Li}\left(\mathrm{BH}_{4}\right)_{1-\mathrm{x}} \mathrm{Br}_{\mathrm{x}}$. The composition of the solid solution $h$ - $\mathrm{Li}\left(\mathrm{BH}_{4}\right)_{1-\mathrm{x}} \mathrm{Br}_{\mathrm{x}}$ appears to remain at constant $\mathrm{x} \sim 0.5$ upon storage at RT for several months, but $\alpha$ - $\mathrm{LiBr}$ and presumably amorphous o- $\mathrm{LiBH}_{4}$ are slowly segregated. Bromide substitution 
clearly stabilizes the hexagonal structure of $\mathrm{LiBH}_{4}$ to $\mathrm{RT}$ as a solid solution with composition $h-\mathrm{Li}\left(\mathrm{BH}_{4}\right)_{0.5} \mathrm{Br}_{0.5}$. However, the Sieverts measurements revealed that the hydrogen uptake and release properties of $h-\mathrm{Li}\left(\mathrm{BH}_{4}\right)_{1-\mathrm{x}} \mathrm{Br}_{\mathrm{x}}$ are similar to those of $\mathrm{LiBH}_{4}$. A new hexalithium borate tribromide, $\mathrm{Li}_{6}\left(\mathrm{BO}_{3}\right) \mathrm{Br}_{3}$ with a hexagonal structure was also discovered in this work. This compound may form upon heating $\mathrm{LiBH}_{4}-\mathrm{LiBr}$ mixtures to temperatures above $280^{\circ} \mathrm{C}$ and reveal the hygroscopic nature of lithium bromide, which may contain water, e.g. in the form $\mathrm{LiBr} \cdot \mathrm{H}_{2} \mathrm{O}$.

\section{Acknowledgements}

The European Commission (contract NMP-2008-261/FLYHY), the Danish Research Council for Natural Sciences (Danscatt) Danish National Research Foundation (Centre for Materials Crystallography), the Danish Strategic Research Council (Centre for Energy Materials) and the Carlsberg Foundation is gratefully acknowledged for financial support to this project. The access to beamtime at the MAX-II synchrotron, Lund, Sweden in the research laboratory MAX-lab is also gratefully acknowledged. Finally we acknowledge the Swiss-Norwegian Beam Lines (SNBL), European Synchrotron Radiation Facility (ESRF), Grenoble, France, for the beamtime allocation.

\section{Appendix. Supplementary material}

Supplementary data related to this article can be found online at doi:10.1016/j.ijhydene.2011.08.087.

\section{REFEREN C ES}

[1] Dresselhaus MS, Thomas IL. Alternative energy technologies. Nature 2001;414:332-7.

[2] Schlapbach L, Züttel A. Hydrogen-storage materials for mobile applications. Nature 2001;414:353-8.

[3] Ritter JA, Ebner AD, Wang J, Zidan R. Implementing a hydrogen economy. Mater Today 2003;6:18-23.

[4] Züttel A. Hydrogen storage methods. Naturwissenschaften 2004;91:157-72.

[5] Eberle U, Felderhoff M, Schüth F. Chemical and physical solutions for hydrogen storage. Angew Chem Int Ed 2009;48: 6608-30.

[6] Mori D, Hirose K. Recent challenges of hydrogen storage technologies for fuel cell vehicles. Int J Hydrogen Energy 2009;34:4569-74

[7] Norek M, Nielsen TK, Polanski M, Kunce I, Plocinski T, Jaroszewicz LR, et al. Synthesis and decomposition mechanisms of ternary $\mathrm{Mg}_{2} \mathrm{CoH}_{5}$ studied using in situ synchrotron X-ray diffraction. Int J Hydrogen Energy 2011;36: 10760-70.

[8] Pitt MP, Paskevicius M, Webb CJ, Sørby MH, Delleda S, Jensen TR, et al. Nanoscopic $\mathrm{Al}_{1-\mathrm{x}} \mathrm{Ce}_{\mathrm{x}}$ phases in the $\mathrm{NaH}+\mathrm{Al}+0.02 \mathrm{CeCl}_{3}$ system. Int J Hydrogen Energy 2011;36: 8403-11.

[9] Polanski M, Nielsen TK, Cerenius Y, Bystrzycki J, Jensen TR. Synthesis and decomposition mechanisms of $\mathrm{Mg}_{2} \mathrm{FeH}_{6}$ studied by in-situ synchrotron $x$-ray diffraction and highpressure dsc. Int J Hydrogen Energy 2010;35:3578-82.
[10] Polanski M, Plocinski T, Kunce I, Bystrzycki J. Dynamic synthesis of ternary $\mathrm{Mg}_{2} \mathrm{FeH}_{6}$. Int J Hydrogen Energy 2010;35: 1257-66.

[11] Jensen TR, Andreasen A, Vegge T, Andreasen JW, Stahl K, Pedersen AS, et al. Dehydrogenation kinetics of pure and nickel-doped magnesium hydride investigated by in situ time-resolved powder X-ray diffraction. Int J Hydrogen Energy 2006;31:2052-62.

[12] Bellosta von Colbe JM, Metz O, Lozano GA, Pranzas PK, Schmitz HW, Beckmann F, et al. Behavior of scaled-up sodium alanate hydrogen storage tanks during sorption. Int J Hydrogen Energy; 2011. doi:10.1016/j.jjhydene.2011.03.153.

[13] Li HW, Yan Y, Orimo S, Züttel A, Jensen CM. Recent progress in metal borohydrides for hydrogen storage. Energies 2011;4: $185-214$

[14] Rude LH, Nielsen TK, Ravnsbæk DB, Bösenberg U, Ley MB, Richter B, et al. Tailoring properties of borohydrides for hydrogen storage: a review. Phys Stat Sol 2011;208:1754-73.

[15] Ravnsbæk DB, Filinchuk Y, Cerný R, Jensen TR. Powder diffraction methods for studies of borohydride-based energy storage materials. Z Kristallogr 2010;225:557-69.

[16] Züttel A, Rentsch S, Fischer P, Wenger P, Sudan P, Mauron P, et al. Hydrogen storage properties of $\mathrm{LiBH}_{4}$. J Alloys Compd 2003;356-7:515-20.

[17] Orimo SI, Nakamori Y, Ohba N, Miwa K, Aoki M, Towata SI, et al. Experimental studies on intermediate compound of $\mathrm{LiBH}_{4}$. Appl Phys Lett 2006;89:021920.

[18] Mosegaard L, Møller B, Jørgensen JE, Bösenberg U, Dornheim $\mathrm{M}$, Hanson JC, et al. Intermediate phases observed during decomposition of $\mathrm{LiBH}_{4}$. J Alloys Compd 2007;446-7: $301-5$.

[19] Friedrichs O, Remhof A, Hwang SJ, Züttel A. Role of $\mathrm{Li}_{2} \mathrm{~B}_{12} \mathrm{H}_{12}$ for the formation and decomposition of $\mathrm{LiBH}_{4}$. Chem Mater 2010;22:3265-8.

[20] Her JH, Yousufuddin M, Zhou W, Jalisatgi SS, Kulleck JG, Zan JA, et al. Crystal structure of $\mathrm{Li}_{2} \mathrm{~B}_{12} \mathrm{H}_{12}$ : a possible intermediate species in the decomposition of $\mathrm{LiBH}_{4}$. Inorg Chem 2008;47:9757-9.

[21] Mauron P, Buchter F, Friedrichs O, Remhof A, Bielmann M, Zwicky CN, et al. Stability and reversibility of $\mathrm{LiBH}_{4}$. J Phys Chem B 2008;112:906-10.

[22] Filinchuk Y, Chernyshov D, Dmitriev V. Light metal borohydrides: crystal structures and beyond. Z Kristallogr 2008;223:649-59.

[23] Dmitriev V, Filinchuk Y, Chernyshov D, Talyzin AV, Dzwilewski A, Andersson O, et al. Pressure-temperature phase diagram of $\mathrm{LiBH}_{4}$ : synchrotron X-ray diffraction experiments and theoretical analysis. Phys Rev B 2008;77: 174112.

[24] Hartman MR, Rush JJ, Udovic TJ, Bowman Jr RC, Hwang SJ. Structure and vibrational dynamics of isotopically labeled lithium borohydride using neutron diffraction and spectroscopy. J Solid State Chem 2007;180:1298-305.

[25] Filinchuk Y, Chernyshov D, Cerný R. Lightest borohydride probed by synchrotron $\mathrm{X}$-ray diffraction: experiment calls for a new theoretical revision. J Phys Chem C 2008;112: 10579-84.

[26] Filinchuk Y, Chernyshov D, Nevidomskyy A, Dmitriev V. High-pressure polymorphism as a step towards destabilization of $\mathrm{LiBH}_{4}$. Angew Chem Int Ed 2008;47:529-32.

[27] Au M, Spencer W, Jurgensen A, Zeigler C. Hydrogen storage properties of modified lithium borohydrides. J Alloys Compd 2008;462:303-9.

[28] Mosegaard L, Møller B, Jørgensen JE, Filinchuk Y, Cerenius Y, Hanson JC, et al. Reactivity of $\mathrm{LiBH}_{4}$ : in situ synchrotron radiation powder X-ray diffraction study. J Phys Chem C 2008;112:1299-303.

[29] Au M, Jurgensen A. Modified lithium borohydrides for reversible hydrogen storage. J Phys Chem B 2006;110:7062-7. 
[30] Au M, Walters RT. Reversibility aspect of lithium borohydrides. Int J Hydrogen Energy 2010;35:10311-6.

[31] Lee JY, Ravnsbæk D, Lee YS, Kim Y, Cerenius Y, Shim JH, et al. Decomposition reactions and reversibility of the $\mathrm{LiBH}_{4}-\mathrm{Ca}\left(\mathrm{BH}_{4}\right)_{2}$ composite. J Phys Chem C 2009;113:15080-6.

[32] Cho YW, Shim JH, Lee BJ. Thermal destabilization of binary and complex metal hydrides by chemical reaction: a thermodynamic analysis. Calphad 2006;30:65-9.

[33] Bösenberg U, Kim JW, Gosslar D, Eigen N, Jensen TR, Bellosta von Colbe JM, et al. Role of additives in $\mathrm{LiBH}_{4}-\mathrm{MgH}_{2}$ reactive hydride composites for sorption kinetics. Acta Mater 2010;58: 3381-9.

[34] Bösenberg U, Doppiu S, Mosegaard L, Barkhordarian G, Eigen N, Borgschulte A, et al. Hydrogen sorption properties of $\mathrm{MgH}_{2}-\mathrm{LiBH}_{4}$ composites. Acta Mater 2007;55:3951-8.

[35] Vajo JJ, Skeith SL, Mertens F. Reversible storage of hydrogen in destabilized $\mathrm{LiBH}_{4}$. J Phys Chem B 2005;109:3719-22.

[36] Nielsen TK, Bösenberg U, Gosalawit R, Dornheim M, Cerenius Y, Besenbacher F, et al. A reversible nanoconfined chemical reaction. ACS Nano 2010;4:3903-8.

[37] Ravnsbæk DB, Jensen TR. Tuning hydrogen storage properties and reactivity: investigation of the $\mathrm{LiBH}_{4}-\mathrm{NaAlH}_{4}$ system. J Phys Chem Sol 2010;71:1144-9.

[38] Nielsen TK, Besenbacher F, Jensen TR. Nanoconfined hydrides for energy storage. Nanoscale 2011;3:2086-98.

[39] Arnbjerg LM, Ravnsbæk DB, Filinchuk Y, Vang RT, Cerenius Y, Besenbacher F, et al. Structure and dynamics for $\mathrm{LiBH}_{4}-\mathrm{LiCl}$ solid solutions. Chem Mater 2009;21:5772-82.

[40] Oguchi H, Matsuo M, Hummelshøj JS, Vegge T, Nørskov JK, Sato $\mathrm{T}$, et al. Experimental and computational studies on structural transitions in the $\mathrm{LiBH}_{4}$-LiI pseudobinary system. Appl Phys Lett 2009;94:141912.

[41] Yin L, Wang P, Fang Z, Cheng H. Thermodynamically tuning $\mathrm{LiBH}_{4}$ by fluorine anion doping for hydrogen storage: a density functional study. Chem Phys Lett 2008;450:318-21.

[42] Brinks HW, Fossdal A, Hauback BC. Adjustment of the stability of complex hydrides by anion substitution. J Phys Chem C 2008;112:5658-61.

[43] Corno M, Pinatel E, Ugliengo P, Baricco M. A computational study on the effect of fluorine substitution in $\mathrm{LiBH}_{4}$. J Alloys Compd 2011;509S:S679-83.

[44] Yin LC, Wang P, Kang XD, Sun CH, Cheng HM. Functional anion concept: effect of fluorine anion on hydrogen storage of sodium alanate. Phys Chem Chem Phys 2007;9:1499-502.

[45] Fonnelop JE, Corno M, Grove H, Pinatel E, Sørby MH, Ugliengo P, et al. Experimental and computational investigations on the $\mathrm{AlH}_{3} / \mathrm{AlF}_{3}$ system. J Alloys Compd 2011;509:10-4.

[46] Ravnsbæk DB, Rude LH, Jensen TR. Chloride substitution in sodiumborohydride. J Solid State Chem 2011;184:1858-66.

[47] Rude LH, Filinchuk Y, Sørby MH, Hauback BC, Besenbacher F, Jensen TR. Anion substitution in $\mathrm{Ca}\left(\mathrm{BH}_{4}\right)_{2}-\mathrm{CaI}_{2}$ : synthesis, structure and stability of three new compounds. J Phys Chem C 2011;115:7768-77.

[48] Lee JY, Lee YS, Suh JY, Shim JH, Cho YW. Metal halide doped metal borohydrides for hydrogen storage: the case of $\mathrm{Ca}\left(\mathrm{BH}_{4}\right)_{2}-$ $\mathrm{CaX}_{2}(\mathrm{X}=\mathrm{F}, \mathrm{Cl})$ mixture. J Alloys Compd 2010;506:721-7.

[49] Rude LH, Groppo E, Arnbjerg LM, Ravnsbæk DB, Malmkjær RA, Filinchuk Y, et al. Iodide substitution in lithium borohydride, $\mathrm{LiBH}_{4}$-LiI. J Alloys Compd 2011;509:8299-305.

[50] Maekawa H, Matsuo M, Takamura H, Ando M, Noda Y, Karahashi T, et al. Halide-stabilized $\mathrm{LiBH}_{4}$, a room-temperature lithium fast-ion conductor. J Am Chem Soc 2009;131:894-5.

[51] Matsuo M, Takamura H, Maekawa H, Li HW, Orimo SI. Stabilization of lithium superionic conduction phase and enhancement of conductivity of $\mathrm{LiBH}_{4}$ by $\mathrm{LiCl}$ addition. Appl Phys Lett 2009;94:084103.

[52] Borgschulte A, Gremaud R, Kato S, Stadie NP, Remhof A, Züttel A, et al. Anharmonicity in $\mathrm{LiBH}_{4}-\mathrm{LiI}$ induced by anion exchange and temperature. Appl Phys Lett 2010;97:031916.

[53] Fischer D, Müller A, Jansen M. Existiert eine wurtzitmodifikation von lithiumbromid? untersuchungen im system LiBr/LiI. Z Anorg Allg Chem 2004;630:2697-700.

[54] Johnson DC. Solid-state chemistry: new order for lithium bromide. Nature 2008;454:174-5.

[55] Liebold-Ribeiro Y, Fischer D, Jansen M. Experimental substantiation of the "energy landscape concept" for solids: synthesis of a new modification of LiBr. Angew Chem Int Ed 2008;47:4428-31.

[56] Cerenius Y, Stahl K, Svensson LA, Ursby T, Oskarsson A, Albertsson J, et al. The crystallography beamline I711 at max ll. J Synchrotron Radiat 2000;7:203-8.

[57] Jensen TR, Nielsen TK, Filinchuk Y, Jørgensen JE, Cerenius Y, Gray EM, et al. Versatile in situ powder X-ray diffraction cells for solid-gas investigations. J Appl Cryst 2010;43:1456-63.

[58] Hauback BC, Fjellvåg H, Steinsvoll O, Johansson K, Buset OT, Jørgensen J. The high resolution powder neutron diffractometer pus at the JEEP 11 reactor at kjeller in Norway. J Neutr Res 2000;8:215-32.

[59] Hammersley AP, Svensson SO, Hanfland M, Fitch AN, Hausermann D. Two-dimensional detector software: from real detector to idealised image or two-theta scan. High Press Res 1996;14:235-48.

[60] Rodriguez-Carvajal J. Fullprof suite. France: LLB Sacley \& lCSIM Rennes; 2003.

[61] Boultif A, Louër D. Powder pattern indexing with the dichotomy method. J Appl Cryst 2004;37:724-31.

[62] Favre-Nicolin V, Cerný R. Fox, 'free objects for crystallography': a modular approach to ab initio structure determination from powder diffraction. J Appl Cryst 2002;35: 734-43.

[63] Gas reaction controller from advanced materials corporation, http://www.advanced-material.com/pci01.htm; 2010.

[64] Weiss E, Hensel HG, Kuehr H. Chemische Berichte 1969;102: 632-42.

[65] Soulie JP, Renaudin G, Cerný R, Yvon K. Lithium boro-hydride $\mathrm{LiBH}_{4}$ l. Crystal structure. J Alloys Compd 2002;346:200-5.

[66] Pistoriu CW. Melting and polymorphism of $\mathrm{LiBH}_{4}$ to $45 \mathrm{kbar}$. Z Phys Chem 1974;88:253-63.

[67] Riktor MD, Filinchuk Y, Vajeeston P, Bardají EG, Fichtner M, Fjellvåg $\mathrm{H}$, et al. The crystal structure of the first borohydride borate, $\mathrm{Ca}_{3}\left(\mathrm{BD}_{4}\right)_{3}\left(\mathrm{BO}_{3}\right)$. J Mater Chem 2011;21:7188-93.

[68] Lee YS, Filinchuk Y, Lee HS, Suh JY, Kim JW, Yu JS, et al. On the formation and the structure of the first bimetallic borohydride borate, $\mathrm{LiCa}_{3}\left(\mathrm{BH}_{4}\right)\left(\mathrm{BO}_{3}\right)_{2}$. J Phys Chem C 2011; 115:10298-304.

[69] Orimo SI, Nakamori Y, Züttel A. Material properties of $\mathrm{MBH}_{4}$ ( $\mathrm{M}=\mathrm{Li}, \mathrm{Na}$, and $\mathrm{K})$. Mater Sci Eng. B 2004;108:51-3.

[70] Gomes S, Hagemann H, Yvon K. Lithium boro-hydride $\mathrm{LiBH}_{4}$ : ll. Raman spectroscopy. J Alloys Compd 2002;346:206-10.

[71] Andresen ER, Gremaud R, Borgschulte A, Ramirez-Cuesta AJ, Züttel A, Hamm P. Vibrational dynamics of $\mathrm{LiBH}_{4}$ by infrared pump-probe and 2d spectroscopy. J Phys Chem A 2009;113: 12838-46.

[72] Tomkinson J, Waddington TC. Inelastic neutron scattering from the alkali metal borohydrides and the calcium borohydride. J Chem Soc Faraday Trans 1976;72:528-38. 